\title{
ON INTERACTIVE PEDAGOGICAL TECHNOLOGIES WHICH CAN ASSIST ENGLISH LANGUAGE STUDENTS TO IMPROVE THEIR LEARNING SKILLS
}

CAzimbaeva R., Tashkent Institute of Finance, Tashkent, Uzbekistan, azimbayevarano@ gmail.com

\section{ОБ ИНТЕРАКТИВНЫХ ПЕДАГОГИЧЕСКИХ ТЕХНОЛОГИЯХ ДЛЯ СТУДЕНТОВ, СПОСОБСТВУЮЩИХ УЛУЧШЕНИЮ НАВЫКОВ ОБУЧЕНИЯ АНГЛИЙСКОГО ЯЗЫКА}

(C)Азимбаева Р. Ю., Ташкентский институт финансов, г. Ташкент, Узбекистан, azimbayevarano@gmail.com

Abstract. The purpose of this study is to consider the effectiveness of using interactive technologies in the process of teaching a foreign language at a higher educational institution. The principal result of our research is the analysis of the influence of using interactive techniques on acquiring communicative competence and personal development of students. The major conclusions estimate the significance of applying interactive technologies in learning process.

Аннотащия. Целью данного исследования является рассмотрение эффективности использования интерактивных технологий в процессе преподавания иностранного языка в вузе. Основным результатом нашего исследования является анализ влияния использования интерактивных методов на развитие коммуникативной компетентности и личностного развития студентов. Основные выводы оценивают значимость применения интерактивных технологий в учебном процессе.

Keywords: interactive technology, interactive method, communication, discussion, brainstorming, case study, role play.

Ключевые слова: интерактивные технологии, интерактивный метод, общение, дискуссия, мозговой штурм, кейс, ролевая игра.

Nowadays, the significance of teaching a foreign language efficient has grown importantly in the world, especially in developing countries, such as Uzbekistan. Considering the state of English as an international language, to encourage its study to spread public access to the world's social, economic, educational and cultural opportunities offered by the knowledge and use of English, ensuring the integration of Republic of Uzbekistan into the world economic, political, scientific and educational space.

In today's global world there is an urgent need to develop the person-oriented curriculum and teaching technologies aimed at efficient professional training of a future specialist. A traditional system of education does not provide with the necessary means of learning process activation and cognitive activity stimulation so interactive technologies are an important part of the learning process. These types of activities also make possible to use all levels of knowledge.

The main objective of the article is analyzing the methodology aspects and the peculiarities of modern interactive pedagogical technologies such as a role-play, case study usage, revealing their potential for stimulation of the learning process in higher education establishments as well as 
outlying the forms and means of introducing into teaching foreign languages for professional and communication training of future specialists.

According to the Decree of the President of the Republic of Uzbekistan Shavkat Mirziyoyev on «Measures for further enhancement of the System of teaching of foreign languages» the system of teaching the foreign languages has been considered. As it is said in the decree to highlight that a complex system for learning and teaching of foreign languages lead on improving of comprehensively developed, advanced, educated and intellectual youth, and further penetration of the Republic of Uzbekistan with the global society has been established within the framework of the Law on Education and the National Programme for Personnel Training.

Based on this Decree a new approach of teaching the foreign languages has been set in higher education in Uzbekistan. So, as a result of discussions in higher education on the quality of teaching and learning, universities have recently began a new to determine their goal and directions by which they reach these. A significant item of this policy has been to describe the disciplinary knowledge and skills, critical thinking skills, attributes and attitudes students are expected to acquire during their study, that's why new approaches were needed to fulfill the task.

As it is known, today there is a significant direction from passive to active learning. Therefore, special attention is paid to improving the technological aspects of specialist training and implementation-centered approach to the learning process where the student takes a key role in cognitive activity. Foreign language teachers must find tools to develop the level of students' involvement in the process of studying, to raise their motivation for learning languages. One way to achieve these goals is using interactive technologies at classes. It provides to develop students' imagination, creativity increase their cognitive interest in studying foreign languages and improve their communicative skills.

The term "interactive learning technology" is usually connected with computer or multimedia learning, as it implies interactive dialogue with real partners and direct exchange of messages. But this notion is wider and means collective cognitive activity where all participants interact, exchange information, solve problems in atmosphere of real collaboration, estimate their own actions.

We have now discussed that the interactive technologies of teaching foreign languages are based on activity-based approach and comprise the use of interactive teaching methods, including dialogue and game, simulation, analysis of situations, auction ideas; organic combination in the educational process of various learning tools, distance-learning and traditional forms of education on the principles of the appropriateness of their implementation.

As we all know very well, the basis of interactive learning is a direct dialogue student teacher, student - student, students - guest. It can be one lesson, a series of lessons or the whole course. Such classification reflects the main features of interactive methods of teaching foreign languages: activity, collectivity and situational training activities; developing students' reflective skills, attention, imagination, observation, innovative thinking; educational consistency, logic, critical thinking and creativity, efficiency, curiosity, cognitive independence and persistence in achieving goals.

In order to train highly skilled specialists, lectures, seminars, laboratories and practical classes, as well as other forms of training, including role places and case studies as interactive methods of teaching foreign languages to students are held. It is noted that when presenting the studying material in a game form, students are active and interested in the results of their educational activities.

In addition to the abovementioned information, we would like to consider closely useful materials and research methods, which are used to help the students to gain the knowledge and help them to achieve their learning targets and to describe the teaching techniques that were applied in 
classroom. The participants were the second year students who have been learning English and two senior teachers who have been teaching English at English course.

This research was conducted by using qualitative descriptive and two techniques for collecting data namely business role-play and case-study. Based on the research findings, we found that all of the selected teachers used these interactive methods of teaching foreign languages as the main teaching methods which were sometimes combined with some techniques of other methods such as training discussions or debates, games.

Considering various kinds of role-plays and case-studies we have to point out that they help to encourage interests of its participants and necessity of making decisions by these interactive methods results. In professional education a role-play and a case-study are kind of methods when the content of future specialists' professional activities is simulated in imaginary situations.

Based on this research's findings, it seems that all of the teachers used role-plays and casestudies in order to provide a student-centered engagement activity to help participants of this educational process, apply learning through problem-based activities that require creative solutions and practical outcomes.

Case studies are typically used to apply several problem-solving concepts and skills to a detailed situation with lots of supporting documentation and data. Case study often involves a reallife, well documented situation and the students' solutions are compared to what was done in the actual case. It generally includes dialogue, creates identification or empathy with the main characters, depending on the discipline. Case studies are best if the situations are recent, relevant to students, have a problem to solve, and involve principles that apply broadly.

Here some suggestions for English teachers, who want to create successful English teaching. In the process of using case studies, its' content should:

connect with students' prior knowledge and help build on it;

be presented in a real world context;

provide some structure and direction but not too much, since self-directed learning is the goal;

have sufficient cues to encourage students to search for explanations;

be interesting, because students should depicted situation connects to personal experiences they've had;

help students fill in knowledge gaps.

In turn, role plays can be short or longer and more complex, like case studies, but without a lot of the documentation. The idea is to enable students to experience what it may be like to see a problem or issue from many different perspectives as they assume a role they may not typically take, and see others do the same.

For example, the main attributes of successful role plays should be:

- simulation of chosen aspect of goal-oriented human activity;

- roles for each participant;

- rulemaking for play activities;

- transformation of space-time characteristics of the simulated activity;

- game conditionality;

- action evaluation of game participants.

Role plays generally have three types of participants: players, observers and facilitator. They also have three phases, as indicated below:

- Briefing phase: This stage provides the warm-up, explanations, and asks participants for input on role play scenario. The role play should be somewhat flexible and customizable to the audience. Good role descriptions are sufficiently detailed to let the average person assume the role 
but not so detailed that there are so many things to remember that it becomes cumbersome. After role assignments, let participants chat a bit about the scenarios and their roles and ask questions.

- Play phase: The facilitator makes seating arrangements, sets up props, arranges any tech support necessary, and does a short introduction. Players play roles, and the facilitator keeps things running smoothly by interjecting directions, descriptions, comments, and encouraging the participation of all roles until players keep things moving without intervention, then withdraws. The facilitator provides a conclusion if one does not arise naturally from the interaction.

- Debriefing phase: Role players talk about their experience to the class, facilitated by the instructor or appointee who draws out the main points. All players should describe how they felt and receive feedback from students and the instructor.

For our first research question, we distributed survey questionnaire among the students. About a hundred students filled up the questionnaire form. About ninety percent students agreed that a role play is different from other activities; about seventy percent students said that a role play helped to increase their speaking ability and they also thought that they could show creativity more in a role play rather than other activities. About fifty percent students found it to be an easy method to communicate as they had complete independent to choose the vocabulary. Only ten percent found it difficult as they had to act and speak.

According to learners' survey results during this process we determined eight main qualities of students formed during a role-play:

1. Skills to communicate in formal and informal situations and interact efficiently on equal terms.

2. Leadership skills.

3. Skills to orientate in conflict situations and resolve them.

4. Skills to obtain and process the necessary information, evaluate, compare and master it.

5. Skills to make decisions in uncertain situations.

6. Time management skills, skills to assign tasks and make time efficient organization decisions.

7. Skills to demonstrate entrepreneur business qualities: to set prospective goals, use favorable opportunities.

8. Skills to evaluate the consequences of their own decisions and learn from mistakes.

So a role-play and a case study form professional basic skills and activate creative abilities of a student and they can be the means of training for certain specialists as well as a team. Having acquired the necessary knowledge students are able to master professions connected with economic and managing mechanisms.

Thus, the usage of role-plays and case studies in teaching foreign languages at higher education allows intensifying the learning process and solving various educational and developing goals. These kinds of activities not only provide students with scientific comprehension results, but also form independence, develop and improve their creative abilities. These interactions are a kind of non-formal communication which helps students to combat some stress and language barriers.

We took a group interview of the students, where forty students sat for the interview to share their views about the advantages and disadvantages of speaking in a large class. Fifteen students stated that as they worked in a group, the students with less confidence benefitted from this as they got support from students who were more confident. As they divided the work into groups, they felt less burdened and it created a scope to show the talent of each individual. Ten students said that as they were confronted with a different situation, they experienced something new and interesting even though the characters in role play were familiar to them. While talking about the disadvantages of role play, five students felt that during role play, out of nervousness, they forgot their dialogues 
and it caused them embarrassment. On the other hand, six students disagreed with the idea and said that even if they forgot the dialogues, they could continue the act by making up dialogues of their own. Four students believed that, at times, it was difficult for them to fully manage the task within the allocated time

We interviewed five teachers to ascertain whether a role play and a case study could bring any effective changes in enhancing learners' speaking skills to communicate and interact accurately. The teachers confirmed that a role play and a case study enhanced learners' speaking skill as it enabled them to get fluency through acting and communicating with others. They also shared that the learners gained confidence after the first act and they tried to improve gradually in the following performances. As the situations were not discussed with the students beforehand, each time they performed, they tried to come up with new ideas. That showed their enthusiasm, interest and creativity

In our research, we have found that students were enthusiastic about role plays and case studies as it was different from other activities done in class. After a series of role plays and case studies, they showed remarkable improvement in their speaking ability and they were also found to be quite fluent. In a large class room, a role play and a case study were good techniques to use to observe the performance of a number of students in a limited time constraint.

For conclusion, in a few words, we can say that a role play and a case study techniques have positive impact in improving learners' speaking skills as its give the students a chance to explore different situations of real life and enables them to speak accurately and confidently in that situation in the target language. Although during these interactive methods in a large class room, the situation gets chaotic and the performers sometimes forget their dialogues, which create embarrassment, eventually with the help of little feedback from the teachers, this problem can be resolved. Teachers may give prompt verbal feedback or written feedback in case of technical difficulties while recording acts.

\section{References:}

1. Ocheretna, N. (2013). Osoblyvosti zastosuvannia dilovykh ihor u protsesi vyvchennia inozemnoi movy u vyshchykh navchalnykh zakladakh [Features of the use of business games in the process of learning a foreign language in higher education]. Teacher education: theory and practice, 14, 206-210. (in Ukrainian).

2. Radjabova, D. A. (2017). Modern educational technologies in teaching a foreign language. Molodoi uchenyi, (13). 592-595. (in Russian).

3. Mavlonova, M. D. (2017). The new pedagogical technologies in teaching the foreign languages in higher education in Uzbekistan. Molodoi uchenyi, (24). 358-360. (in Russian).

4. Brown, H. D. (2016). Teaching by principles.

5. Al-Senaidi, S. A. (2010). Using role play to promote oral fluency. Retrieved May 24th.

\section{Список литературь:}

1. Ocheretna N. D. Osoblyvosti zastosuvannya dilovyx igor u procesi vyvchennya inozemnoyi movy u vyshhyx navchalnyx zakladax [Features of the use of business games in the process of learning a foreign language in higher education] // Pedagogical Education: Theory and Practice. 2013. Vol. 14. P. 206-210.

2. Раджабова Д. А. Modern educational technologies in teaching a foreign language // Молодой ученый. 2017. №13. С. 592-595.

3. Мавлонова М. Д. The new pedagogical technologies in teaching the foreign languages in higher education in Uzbekistan // Молодой ученый. 2017. №24. С. 358-360. 
4. Brown, H. D. Teaching by principles. 2016.

5. Al-Senaidi S. A. Using role play to promote oral fluency // Retrieved May 24th. 2010.

Ссылка для циитирования:

Azimbaeva R. On Interactive Pedagogical Technologies Which Can Assist English Language Students to Improve Their Learning Skills // Бюллетень науки и практики. 2020. Т. 6. №4. С. 416-421. https://doi.org/10.33619/2414-2948/53/47

Cite as (APA):

Azimbaeva, R. (2020). On Interactive Pedagogical Technologies Which Can Assist English Language Students to Improve Their Learning Skills. Bulletin of Science and Practice, 6(4), 416421. https://doi.org/10.33619/2414-2948/53/47 